DOI: $10.22616 /$ j.balticsurveying.2018.022

\title{
UTILIZATION OF AGRICULTURAL LAND IN THE RUSSIAN FEDERATION
}

\author{
Sergey Volkov, Vladimir Kosinsky \\ The State University of Land Use Planning
}

\begin{abstract}
This article reviews the initiatives for setting up rational use and protection of agricultural lands in order to ensure accelerated growth of the agricultural sector of the Russian Federation, enhancing its sustainability, efficiency, competitiveness, and environmental safety. It is hereby proposed to complete the differentiation of public lands into federal property, property of the subjects of the Russian Federation, property of municipal settlements; as well as to conduct topographic survey of lands in the Russian Federation (to establish and locally document the boundaries of territories of the subjects of the Russian Federation; municipal settlements; communities; special-purpose lands; areas with special land use conditions; and to systematically (once every 5 years) perform agricultural land inventory in order to identify unused, irrationally used or non-purposely used lands, as well as land use in violation of the relevant permitted use of land plots; to relaunch land survey works relating with the performance of pedologic, geobotanical and other studies and research.
\end{abstract}

Key words: land management, agricultural land, land utilization, land protection.

\section{Introduction}

Ensuring food security in the Russian Federation is one of the priorities of socio-economic development of the Russian Federation. The degree of success of this strategy largely depends on the level of efficiency of using agricultural lands, both currently and in foreseeable future.

Russia's agricultural sector has lately demonstrated sustainable growth in terms of manufacture of agricultural products. However, the sector's land potential allows for higher growth rates, provided there is objective evaluation of the condition and well-grounded determination of the trends and contents of activities of the land administration of land resources and setting up rational land ownership and land utilization.

The existing land- and resource potential of our country and, primarily, its agricultural lands is currently estimated at being around 30\% lower than the level of 1990. One can assuredly state that the land reforms of 1990-2017 yielded much more negative outputs than the positive ones when it comes to the issue of land utilization.

On the one hand, successful farming and agricultural entities, due to efficient land organization involving environmental protection activities, are able to ensure sustainable yields, even during years with clearly unfavorable weather conditions. On the other hand, there are substantial reserves in terms of involvement of lands in agriculture.

According to the relevant statistical records, as of January 1, 2017 in the Russian Federation there were 383.6 million hectares of agricultural lands including 197.7 million hectares of arable lands, of which 122.8 million hectares of tillable lands (Table 1) (Волков, 2017).

Entities and persons engaged in agricultural production used 521.4 million hectares of lands, of which agricultural lands accounted for more than 349.2 million hectares $(65.2 \%)$. This is the area composed of 60 million land plots and it is the subject of land relations, while more than 40 million land owners, agricultural tenants, and land users engaged in farming or those affiliated with any cadastral issues acted in the capacity of subjects of land relations (Table 2) (Волков, Липски, 2016). 
Allocation of the land fund of the Russian Federation by land category

Table 1

\begin{tabular}{|c|c|c|c|c|c|c|}
\hline & \multirow[b]{2}{*}{ Land Category } & \multirow{2}{*}{ 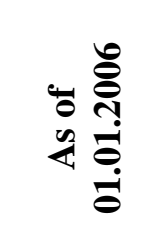 } & \multirow{2}{*}{ 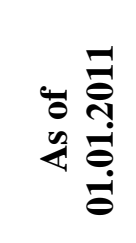 } & \multirow{2}{*}{ 突 } & \multicolumn{2}{|c|}{2017 vs. 2006} \\
\hline & & & & & 咅 & $\%$ \\
\hline 1 & Agricultural lands & 401.6 & 393.4 & 383.6 & -16.0 & -4.0 \\
\hline 2 & Urban lands & 19.1 & 19.6 & 20.4 & +1.3 & +4.8 \\
\hline 3 & $\begin{array}{l}\text { Industrial lands and } \\
\text { special-purpose lands }\end{array}$ & 16.7 & 16.8 & 17.4 & +0.5 & +2.9 \\
\hline 4 & $\begin{array}{l}\text { Lands of specially } \\
\text { protected areas }\end{array}$ & 34.2 & 34.9 & 47.3 & +13.1 & +37.5 \\
\hline 5 & Forest reserve lands & $1,104.9$ & $1,115.8$ & $1,126.3$ & +17.7 & +1.6 \\
\hline 6 & Water fund lands & 27.9 & 28.0 & 28.1 & +0.1 & +0.4 \\
\hline 7 & Undistributed lands & 105.4 & 101.3 & 89.5 & -15.9 & -15.1 \\
\hline & Total lands & $1,709.8$ & $1,709.8$ & $1,712.5$ & +0.1 & - \\
\hline
\end{tabular}

Table 2

Trends of allocation of agricultural lands by business pattern

\begin{tabular}{|c|l|c|c|c|c|c|}
\hline \multirow{2}{*}{ Business pattern } & \multicolumn{2}{|c|}{$\mathbf{2 0 0 6}$} & \multicolumn{2}{c|}{$\mathbf{2 0 1 6}$} & \multirow{2}{*}{$\begin{array}{c}\text { 2016 vs. 2006 } \\
\text { \% vs. \% }\end{array}$} \\
\cline { 3 - 6 } & & $\begin{array}{l}\text { Million } \\
\text { hectares }\end{array}$ & \% & $\begin{array}{c}\text { Million } \\
\text { hectares }\end{array}$ & \% & \multirow{2}{*}{} \\
\hline 1 & Agricultural organizations & 410.3 & 91.0 & 291.6 & 83.5 & -8.2 \\
\hline 2 & Farms & 26.0 & 5.8 & 37.9 & 10.8 & +.0 \\
\hline 3 & Sole proprietors & 3.4 & 0.8 & 5.4 & 1.5 & +0.7 \\
\hline 4 & $\begin{array}{l}\text { Private subsidiary farm and } \\
\text { other private farms }\end{array}$ & 9.7 & 2.2 & 13.1 & 3.8 & +1.6 \\
\hline 5 & Nonprofit private entities & 1.2 & 0.3 & 1.2 & 0.3 & 0 \\
\hline & Total & $\mathbf{4 5 0 . 6}$ & $\mathbf{1 0 0}$ & $\mathbf{3 4 9 . 2}$ & $\mathbf{1 0 0}$ & - \\
\hline
\end{tabular}

Thus, hundreds of millions of hectares of land used in the agricultural sector of the Russian Federation, tens of millions of land owners, agricultural tenants, and land users who are engaged in land relations of various forms require specific organization and management, which is impossible without the corresponding institutions, infrastructure, and mechanisms, the lack of which spawns multiple issues and thus require the appropriate science-based and practical resolution.

\section{Methodology of research and materials}

What is required to meet the above targets?

- Analysis of the condition and organization of agricultural land utilization in 1990-2018, identification of the key trends for the establishment and development of agricultural tenure, and determination of the main areas for setting up rational utilization and protection of agricultural lands in the near-term and for the period ending in 2030 (Хлыстун, 2018);

- Analysis of the land laws and the practice of legal enforcement in the area of setting up the use and protection of agricultural lands, and development of proposals for their further improvement (Волков, Липски, 2018);

- Determination of the trends in the development of land- and property relations in the area of the agricultural sector, evaluation of the status of government-induced registration, cadastral accounting, and cadastral valuation of agricultural lands, and drafting of proposals for the improvement of the state regulation of their circulation; 
- Definition of the condition, scope, and qualitative characteristics of unused farmlands, and develop recommendations for their engagement in agricultural circulation, melioration, and reclamation;

- Determination of losses of the national agricultural sector due to withdrawal of agricultural lands for use in industrial, transport, energy, and residential construction, as well as lands used for any other non-agricultural purposes, and establish measures for their protection and reimbursement of damages and losses of the agricultural sector;

- Substantiation of the need for comprehensive land survey- and cadastral works in rural areas and drafting of design and estimate documentation for land tenure documentation in case of any changes in production and territory;

- Evaluation of the areas of high-value agricultural lands, evaluation of the degree of their degradation, desertification, water erosion, deflation, and any other adverse effects based on the materials of studies and monitoring of agricultural lands and their zoning in terms of their fitness for use in agriculture;

- Calculate economic efficiency of the proposed activities in terms of using lands for the nation's agricultural sector until 2030 (Волков, Липски, 2018). Methodology of research and materials should explain the data source (if any) and the empirical methodologies used in the manuscript. Proper reference should be maintained, if the paper is produced by following any published methods. It should describe what was actually done including description of the techniques used so someone could figure out what experiments were actually done.

\section{Discussions and results}

Therefore regulatory framework in the area of land relations pertaining to agricultural lands should include (Волков, Липски, 2016):

- Inventory of the norms of the federal and regional legislation which regulate utilization and protection of agricultural lands;

- Determination of trends and measures for the improvement of the said legislation, as well as evaluation of the system of government supervision and municipal control over compliance with the same;

- Development of the concept of improvement of the legislation in the part of harmonization of issues of management of land plots, ensuring rational utilization of lands and protection thereof. Introduction of prohibition of withdrawal of high-value farmlands;

- Introduction of restrictions for withdrawal of agricultural lands by way of regulation (establishment of the types of permitted use and restriction of the relevant development density);

- Introduction of amendments and addenda into legislative enactments of the Russian Federation pertaining to the development of real property cadaster for the formation and informing about the properties of real estate items by way of land tenure, as well as in order to exclude land survey work from cadastral activities and appropriation of their independent status;

- Introduction of amendments into the legislation which provide for conduction of specialized auctions for provision of land plots exclusively to SMEs (Small and Medium-sized Enterprises), as well as one-time provision of agricultural land plots without a tender to novice farms (farmers);

- Establishment of a single, maximum size of a land plot for the subjects of the Russian Federation as located in the territory of one municipal district and which may be owned by one person and/or one legal entity or a group of persons and inclusion of this size in the Federal Law dated 24.07.2002 No. 101-FZ On Agricultural Land Transactions;

- Formalization of liability of persons and entities for any degradation and wasteful utilization of land plots (Волков, Липски, 2018)

Improvement of the legal and regulatory issues in the area of land utilization should be aimed at:

- Segregation of functions, authority, and setting up interaction of the federal executive authorities between their own branches and agencies and executive authorities of the subjects of the Russian Federation in the area of legal relations and management of land resources and land tenure;

- Harmonization of the land laws and regulatory enactments with the international law in the area of managing land resources and land tenure, as well as harmonization with the urban planning laws, forestry laws, water resource laws, and other bodies of law; 
- Legislative recognition of the forms and methods of participation of self-regulating entities and persons in land tenure activities.

- Further development of the new draft and introduction of amendments and addenda into the Federal Law dated 18.06.2001 No. 78-FZ On Land Utilization in the section of differentiation of land utilization as government-sponsored and self-motivated, stiffening of requirements to the compulsory nature of land tenure and compliance by titleholders of land plots with the approved land tenure documentation.

Specification of regulatory enactments for the procedure of withdrawal of land plots for governmentand municipal needs; the procedure of changing and delimiting (restoration) borders of the subjects of the Russian Federation, municipal and other administrative and territorial units, and settlement of disputes arising between them with regards to border delimitation;

- Preparation of regulatory enactments aimed to improve the procedure of execution of land title for the construction of linear-type production facilities (power distribution lines, communications lines, pipelines, transportation lines, etc.), agricultural (land utilization) zoning and determination of the legal regime for using lands outside of settlements, especially in urbanized rural settlements, locations with intensive exploration of mineral resources, allotment of land plots as limited interest in joint property to a land plot;

- Specification of the existing regulatory enactments in the part of regulation of land relations and land tenure in the areas of traditional residence of small-numbered indigenous peoples of the North, Siberia, and the Far East of the Russian Federation (Волков, Липски, 2016).

Due to the above, ensuring rational land utilization and protection of agricultural lands should include:

- Completion of differentiation of public lands into federal property, property of the subjects of the Russian Federation, property of municipal settlements;

- Conduction of topographic survey of lands in the Russian Federation (to establish and locally document the boundaries of territories of the subjects of the Russian Federation; municipal settlements (municipal districts, urban settlements, urban districts, rural districts, rural settlements, closed administrative territorial units); communities; special-purpose lands; areas with special land use conditions; territorial cones, as well as parts of the said territories and areas) (Волков, Косинский, 2013);

- Systematic (once every 5 years) performance of agricultural land inventory in order to identify unused, irrationally used or non-purposely used lands, as well as land use in violation of the relevant permitted use of land plots.

- Relaunch of land survey works relating with the performance of pedologic - geobotanical,- and agricultural land surveys, evaluation of their qualitative characteristics, updating of the data of the state cadastral valuation of lands, as well as assessment of the quality of lands relating with the original ecosystem of the indigenous minority peoples of the North, Siberia, and the Far East of the Russian Federation;

- Targeted land utilization activities in order to research and identify the condition and utilization of slough, arid glazing lands, and reclaimed lands;

- Sustainable development, for purposes of comprehensive planning, of rural areas and territories, enhancement of efficiency of the regional and municipal agricultural sector in terms of land management of area owned by the subjects of the Russian Federation, as well as schemes for land management of municipalities;

- Experimental land utilization activities aimed at zoning of agricultural lands and determination of the relevant regulations for land plot usage;

- Zoning of rural (inter-settlement) territories of the subjects of the Russian Federation and municipal settlements in terms of their fitness of use in agriculture; and based on the above development of the land use regulations and regulations for the development of agricultural lands, development of agricultural (land use) regulations, limiting dimensions (maximum and minimum) of land plots (Волков, 2015);

- Development of projects aimed at redistribution of lands and land plot surveys in order to engage 17.2 million hectares of unused land lots in agricultural and economic circulation; 
- Reorganization of territories of defunct farming entities in the area of 15.9 million hectares, the lands of which were accounted in the relevant cadastral documents as lands used by agricultural manufacturers, while the titleholders to such lands had been excluded from the corresponding registers of legal entities and persons;

- Consolidation of land plots from redistribution in the area of 43.7 million hectares including 11.9 million hectares of farmlands, of which 3.5 million hectares are plough lands, within the borders of municipal districts for purposes of ensuring their efficient use, by way of renting them out or sale on competitive terms;

- Identification, delimitation of borders, location, and area of 24.4 million hectares of farmlands allocated to other land categories (excluding agricultural lands) and taking measures for their subsequent utilization in order to manufacture agricultural products or in order to exclude them from agriculture and to draft programs for the development of new lands instead of the lands withdrawn from such agricultural circulation;

- Temporary closing of inefficient and industrially-contaminated farmlands by way of developing the corresponding land use projects and setting up their implementation mechanisms;

- Ensuring intra-farm land tenure for purposes of setting up rational utilization of agricultural lands and their protection, as well as utilization and protection of the lands used by communities of smallnumbered indigenous peoples of the North, Siberia, and the Far East of the Russian Federation in order to guarantee their traditional lifestyle;

- Ensuring the following types of works in case of intra-farm land tenure activities (Волков, Косинский, 2013):

a) Setting up rational utilization by persons and legal entities of land plots designed for agricultural production, as well as setting up territories used by communities of small-numbered indigenous peoples of the North, Siberia, and the Far East of the Russian Federation, in order to guarantee their traditional lifestyle;

b) Development of activities aimed at the improvement of farmlands, development of new lands, reclamation and preservation of lands, cultivation of disturbed lands, protection of lands from erosion, mudflows, saturation, mire formation, resalting, drying out, compaction, pollution with industrial waste and household waste, contamination with radioactive and chemical substances, poisoning, and other adverse effects;

- Ensuring substantiation of land utilization and improvement of soil quality, afforestation amelioration, hydrotechnical construction, infrastructure development of agricultural lands;

- Land utilization-related assistance to farming entities included in the government programs for agricultural development, development of the raw materials- and food markets; improvement of soil quality; melioration and land reclamation; as well as implementation of priority national projects aimed at the agricultural sector development (Волков, Косинский, 2013).

\section{Conclusions}

Thus, the development and implementation of the recommendations for the use of agricultural lands in the short-term - (until 2020) and long-term perspective (until 2030) will allow for substantial changes in the existing approaches to setting up the utilization and protection of the country's land potential, as well as to engage agriculturally-fit unused lands and to rationally organize intersettlement territories, ensure protection of lands from any embezzlement and degradation, and increase the yield of each and every hectare based on the application of advanced technologies.

\section{References}

1. Волков С. Н., Липски С. А. (2018) Особенности правового регулирования земельных отношений в АПК в современных условиях и первоочередные землеустроительные меры по реализации соответствующих законодательных норм (Features of the legal regulation of land relations in the agricultural sector under current conditions and priority land surveying measures aimed at implementing the corresponding legislative regulation) // Землеустройство, кадастр и мониторинг земель. - 2018. - №4, с.510 (in Russian).

2. Волков С.Н.(2017) Современное состояние земельных отношений, землепользования и землеустройства в Российской Федерации и научное обоснование основных направлений их регулирования в АПК (Current condition of land relations, land utilization, and land use planning in the 
Russian Federation and scientific substantiation of the main areas of their regulation of the same in the agricultural sector) / ГУЗ. - M. 72 c. (in Russian).

3. Волков С.Н., Липски С.А. (2016) Проблемы действующего правового механизма выявления неиспользуемых земель принудительного прекращения прав на них и их последующего вовлечения в хозяйственный оборот (The problems of the current legal framework for the identification of unused land and forced termination of rights to them and their subsequent drawing into economic circulation) // O совершенствовании законодательного регулирования оборота земель сельскохозяйственного назначения. Аналитический вестник №24 (623). - М.: Совет Федерации Федерального Собрания Российской Федерации, с. 14-18 (in Russian).

4. Волков С.Н. (2015) О критериях и порядке отнесения земельных участков к особо ценным сельскохозяйственным землям (On the criteria and procedure of allocation of land plots to high-value agricultural lands) // Землеустройство, кадастр и мониторинг земель. - 2015. - №1. - с. 6-13 (in Russian).

5. Волков С.Н. (2015) Землеустроительное обеспечение перехода от категорий земель к территориальному зонированию: [текст выступления на парламентских слушаниях] (Ensuring land use transfer from the categories of land to land zoning: [Transcript of the speaking engagement at parliamentary hearings]) // Землеустройство, кадастр и мониторинг земель. - 2015. - №8, - c.6-9 (in Russian).

6. Волков С.Н., Косинский В.В. (2013) Концепция землеустройства в Российской Федерации на современном этапе (The concept of land utilization in the Russian Federation at the current stage) // Baltic Surveying, 2013: Proceedings of the International Scientific Methodical Conference. - Kaunas: Akademija, c. 157-163 (in Russian).

7. Хлыстун В. Н. (2018) Структурные изменения в земельном фонде России (Structural changes in the Russian land reserves) // Землеустройство, кадастр и мониторинг земель. - 2018. - №4, с.11-18 (in Russian).

8. Хлыстун В.Н., Волков С.Н., Комов Н.В. (2014) Управление земельными ресурсами в России (Management of the land resources in the Russian Federation) // Экономика сельскохозяйственных и перерабатывающих предприятий. - 2014. - №2. - C.41-43 (in Russian).

9. State University of Land Use Planning (SULUP). Volkov S.N. (2014) Land policy of Russia. Millennium experience. Academic and scientific edition. / Volkov S.N., Shirokorad I.I. M.: SULUP. 520 p.

Information About the Authors

Sergey Nikolaevich Volkov, Rector of the State University of Land Use Planning, Academician of the Russian Academy of Sciences, Meritorious Scientist of the Russian Federation, Head of the Land Utilization Department, Doctor of Economics, Professor. The State University of Land Use Planning (SULUP). Address: 15 Kazakova St., Moscow 105064 Russian Federation. Phone: +7 (499) 261-31-46; Email: info@guz.ru. The area of scientific interests: The economics of land utilization, land use planning and cadasters; the theory and methods of modernday land use planning, and the systems of automated design of land utilization.

Vladimir Vasilyevich Kosinsky, Doctor of Economics, Professor of the Land Utilization Department, Meritorious Culture Professional of the Russian Federation, Academician of the Russian Academy of Natural Sciences. The State University of Land Use Planning (SULUP). Address: 15 Kazakova St., Moscow 105064 Russian Federation. Phone: +7 (915) 339-35-45; Email: kosinskij1@ mail.ru. The area of scientific interests: The history of land utilization; methods of the design and substantiation of intra-farm land use and taking into account the land use systems and agriculture systems, and environmental management activities. 